\title{
The role of Asia in the global trade in CITES II-listed poison arrow frogs: hopping from Kazakhstan to Lebanon to Thailand and beyond
}

\author{
Vincent Nijman • Chris R. Shepherd
}

Received: 7 July 2009/Accepted: 13 February 2010/Published online: 9 March 2010

(C) The Author(s) 2010. This article is published with open access at Springerlink.com

\begin{abstract}
We report on the international trade in South American poison arrow frogs (Dendrobatidae) in the period 2004-2008, and focus on the role of Asian countries. All species of dendrobatid frogs are included in Appendix II of the Convention on International Trade in Endangered Species of Wild Fauna and Flora (CITES), regulating all commercial trade in these species. Based on data compiled in the WCMC CITES database, we establish that $>63,000$ dendrobatid frogs (of 32 species) were traded internationally. For 21 species the majority of individuals were reported as captive-bred. A quarter to a fifth of the commercial trade in dendrobatid frogs in terms of volume is destined for Asian markets (mainly Japan, Thailand and Taiwan, Province of China). Kazakhstan, the main supplier for the Thai market, is reported as a source country for 16 species, all captivebred. We found large discrepancies between the reported export of dendrobatid frogs from Kazakhstan-none - and imports reported by Thailand as coming from Kazakhstan $(>2,500$ individuals). A significant part of the trade flow goes via Lebanon, a non-CITES Party. We urge the CITES Management Authorities of the countries involved to investigate the trade in dendrobatid frogs to ensure it does not violate the rules and intentions of CITES.
\end{abstract}

Keywords Amphibians - Conservation - Endangered species · Southeast Asia · Wildlife trade

V. Nijman · C. R. Shepherd

Oxford Wildlife Trade Research Group, School of Social Sciences and Law,

Oxford Brookes University, Oxford OX3 0BP, UK

V. Nijman · C. R. Shepherd

Zoological Museum, University of Amsterdam, PO Box 94766, 1090 GT Amsterdam, The Netherlands

C. R. Shepherd $(\bowtie)$

TRAFFIC Southeast Asia, Unit 3-2, 1st floor, Jalan SS23/11, Taman SEA, Petaling Jaya, Selangor, Malaysia

e-mail: cstsea@po.jaring.my 


\section{Introduction}

A significant part of the pet trade deals with tropical species, from tropical to temperate countries and increasingly to meet domestic demand in tropical countries (Duarte-Quiroga and Estrada 2003; Shepherd et al. 2004; Nijman 2005). Furthermore, as apparently there are many affluent buyers in developing countries, there is a market for exotic pets (i.e. those species not indigenous to the country itself) within the developing world (Nijman and Shepherd 2007): given that wildlife protection laws are not always strictly enforced in certain countries this included species that are not permitted to be traded or species for which trade is strictly regulated (Nijman 2006, 2010; Shepherd et al. 2004). In this paper we focus on the international trade in poison arrow frogs for the pet market, with a focus on the Asian consumer countries.

Poison arrow frogs (Dendrobatidae) are a highly species family of frogs occurring in Central and South America (Clough and Summers 2000; Vences et al. 2000; Bartlett 2003; Symula et al. 2003). Like other tropical frogs they are affected by habitat loss and chytridiomycosis (an infectious disease caused by a zoosporic fungus Batrachochytrium dendrobatidis leading to sometimes high mortalities in amphibians: Daszak et al. 2003), but unsustainable capture for the pet trade may pose an additional threat (Schlaepfer et al. 2005; Gorzula 1996; Preece 1998). At least 30-40 species are encountered regularly in the international pet trade. Recognising the need for regulating trade in dendrobatid frogs, on 22 October 1987 they were listed in Appendix II of the Convention on International Trade in Endangered Species of Wild Fauna and Flora (CITES), regulating all commercial trade in these species (Gorzula 1996; Mrosovsky 1988; Pickett 1987). By then all range countries of dendrobatid frogs - that is countries in which the species occur naturally-were a Party to CITES.

This paper provides an analysis of data available on the international trade in dendrobatid frogs and point at a curious trade route, with captive-bred specimens being exported by one CITES Party (Kazakhstan) to a non-CITES Party (Lebanon), after which they are then re-exported to another CITES Party (Thailand) only to be re-exported further into Asia.

\section{Methods}

Data were obtained from the WCMC-CITES database (http://www.unep-wcmc.org/ citestrade). This database reports all records of import, export and re-export of CITESlisted species as reported by Parties. We focus on commercial trade in live poison arrow frogs only, during the period 2004-2008 inclusive, and focus on the numbers reported by the importing Party. Imports for non-commercial purposes, e.g. exchange between zoos or export for scientific purposes, over this period involved $<700$ live individuals and are excluded here. Numbers of dendrobatid frogs in international zoos and aquariums (excluding hybrids) were retrieved from the International Species Information System website (https://app.isis.org/) listing collection information from its 735 institutional members (zoos, aquariums, and other zoological collections).

Systematics of poison arrow frogs is a field in motion, with seemingly ever-changing genus and species names; for consistency we followed the taxonomy as used in the WCMC-CITES database which is based on Frost (2004) and Brown et al. (2006). Definitions in this paper follow those of CITES (2009): 'captive-bred' refers to at least second generation offspring of parents bred in a controlled captive environment (or first 
generation offspring from a facility that is managed in a manner that has been demonstrated to be capable of reliably producing second-generation offspring in a controlled environment); ' $\mathrm{F} 1$ captive-bred' refers to specimens born in captivity to wild-caught parents and that are not considered as captive bred under CITES; 'ranch-raised' refers to specimens either directly removed from the wild and reared in a controlled environment or progeny from gravid females captured from the wild; 'wild-caught' refers to specimens that originate from the wild. While we know to which country specimens are imported, and for what purposes, we do not have information who are the individuals or organisations behind the imports; therefore 'country $\mathrm{X}$ imports....' is shorthand for 'traders or other individuals or institutions operating in country $\mathrm{X}$ import...' and does not necessary imply that it is the government or government institutions of country $\mathrm{X}$ that does the importing.

\section{Results}

From 2004 to 2008, a total of 32 species were reported to CITES as being commercially traded, totalling 63,165 specimens of live dendrobatid frogs of four genera, i.e. Dendrobates, Phyllobates, Epipedobates and Cryptophyllobates (Table 1). For all but one species (E. trivittatus), the majority of individuals was reported as captive-bred, with all imports for 21 species declared as originating from captive-bred sources (captive-bred and F1 captive born). Seven species are ranched in relatively small numbers (mainly in Panama and Peru) and imports of five species include wild-caught individuals (from Guyana, Panama and Suriname).

About a quarter to a fifth of the commercial trade in dendrobatid frogs in terms of volume is destined for Asian markets. Within Asia, the major importers are Japan $(>4,000$ specimens), Thailand ( $>2,500$ specimens) and Taiwan, Province of China $(>2,000$ specimens). Japan imports most of its dendrobatid frogs from European exporters, Taiwan mainly from European and North American exporters, but Thailand imports mainly from Central Asian suppliers, in particular Kazakhstan.

We found a strong discrepancy between the export data of dendrobatid frogs reported by Kazakhstan and the import data reported by Thailand. Kazakhstan is reported as a source country for 16 species, all reported to be captive-bred, totalling 2,665 specimens (Table 1). For 11 species at least a third of the total global trade during this period is reported to originate from Kazakhstan. However, trade in dendrobatid frogs from Kazakhstan is restricted to the years 2004 and 2005, and while exports from Kazakhstan dominated the international dendrobatid frog trade in these 2 years, no trade is recorded to any county in the years before or after. Kazakhstan, Party to CITES since 2000, has not reported any export in dendrobatid frogs, or any other amphibian, to the CITES Secretariat. Furthermore, no imports have been reported by Kazakhstan nor has any Party reported the export of dendrobatid frogs to Kazakhstan.

According to Thailand's import records, all specimens from Kazakhstan were first exported to Lebanon and subsequently re-exported to Thailand. The only other country from where Thailand imported dendrobatid frogs for commercial purposes was Ukraine (in 2004, 50 captive-bred D. auratus and 26 P. vittatus). Of the 2,665 dendrobatid frogs imported by Thailand originating from Kazakhstan, 105 were re-exported to Taiwan, Province of China, 50 to the Republic of Korea and 6 to the Philippines (Table 2; Fig. 1). 
Table 1 Commercial import of live CITES Appendix II-listed poison arrow frogs in 2004-2008 as reported by parties to CITES, highlighting the role of Kazakhstan as an exporter in the trade in captive-bred individuals (numbers in bold indicate those species for which Kazakhstan is reported as the source of more than a third of the specimens traded)

\begin{tabular}{|c|c|c|c|c|c|c|}
\hline \multirow[t]{2}{*}{ Species } & \multirow[t]{2}{*}{ Total } & \multirow{2}{*}{$\begin{array}{l}\text { Wild- } \\
\text { caught }\end{array}$} & \multirow{2}{*}{$\begin{array}{l}\text { Ranch- } \\
\text { raised }\end{array}$} & \multirow{2}{*}{$\begin{array}{l}\text { F1 captive- } \\
\text { born }\end{array}$} & \multicolumn{2}{|c|}{ Captive-bred } \\
\hline & & & & & Global & Kazakhstan \\
\hline Dendrobates amazonicus & 20 & 0 & 0 & 0 & 20 & 20 \\
\hline Dendrobates auratus & 36,080 & 620 & 1100 & 48 & 33,510 & 200 \\
\hline Dendrobates azureus & 1177 & 0 & 0 & 1 & 996 & 445 \\
\hline Dendrobates duellmani & 80 & 0 & 0 & 0 & 80 & 0 \\
\hline Dendrobates fantasticus & 429 & 0 & 32 & 8 & 389 & 60 \\
\hline Dendrobates fulguritus & 27 & 0 & 0 & 0 & 27 & 0 \\
\hline Dendrobates galactonotus & 388 & 0 & 0 & 11 & 377 & 200 \\
\hline Dendrobates histrionicus & 19 & 0 & 0 & 0 & 19 & 0 \\
\hline Dendrobates imitator & 643 & 0 & 64 & 28 & 551 & 50 \\
\hline Dendrobates lamasi & 284 & 0 & 0 & 12 & 271 & 80 \\
\hline Dendrobates leucomelas & 849 & 389 & 0 & 33 & 427 & 200 \\
\hline Dendrobates mysteriosus & 7 & 0 & 0 & 0 & 7 & 0 \\
\hline Dendrobates pumilio & 14,956 & 400 & 0 & 24 & 14,370 & 200 \\
\hline Dendrobates quinquevittatus & 28 & 0 & 0 & 0 & 28 & 0 \\
\hline Dendrobates reticulatus & 666 & 0 & 0 & 90 & 576 & 200 \\
\hline Dendrobates tinctorius & 1829 & 175 & 0 & 381 & 1273 & 400 \\
\hline Dendrobates truncatus & 33 & 0 & 0 & 0 & 33 & 0 \\
\hline Dendrobates vanzolinii & 36 & 0 & 0 & 0 & 36 & 0 \\
\hline Dendrobates variabilis & 180 & 0 & 56 & 7 & 117 & 0 \\
\hline Dendrobates ventrimaculatus & 1616 & 0 & 88 & 265 & 1313 & 60 \\
\hline Dendrobates spp & 116 & 6 & 0 & 0 & 110 & $\mathbf{5 0}$ \\
\hline Phyllobates bicolor & 225 & 0 & 0 & 5 & 220 & 200 \\
\hline Phyllobates lugubris & 30 & 0 & 0 & 0 & 30 & 0 \\
\hline Phyllobates terribilis & 342 & 0 & 0 & 95 & 287 & 200 \\
\hline Phyllobates vittatus & 97 & 0 & 0 & 0 & 97 & 0 \\
\hline Epipedobates bassleri & 573 & 0 & 110 & 101 & 362 & 0 \\
\hline Epipedobates cainarachi & 6 & 0 & 6 & 0 & 0 & 0 \\
\hline Epipedobates hahneli & 100 & 0 & 10 & 0 & 90 & 0 \\
\hline Epipedobates parvulus & 10 & 0 & 0 & 0 & 10 & 0 \\
\hline Epipedobates pictus & 60 & 0 & 0 & 40 & 20 & 0 \\
\hline Epipedobates tricolor & 213 & 0 & 0 & 14 & 199 & 100 \\
\hline Epipedobates trivittatus & 1821 & 1568 & 73 & 156 & 24 & 0 \\
\hline Cryptophyllobates azureiventris & 225 & 0 & 155 & 30 & 40 & 40 \\
\hline
\end{tabular}

\section{Discussion}

This analysis shows high levels of international trade in dendrobatid frogs, six times higher than reported by Gorzula (1996) more than a decade ago. Compared to the late 1980s-early 1990s (Gorzula 1996), 12 species were no longer reported to be in international trade whereas 18 new ones appeared in recent years. There are large differences between 
Table 2 Commercial imports of live captive-bred CITES Appendix II-listed poison arrow frogs in 19872008 with Kazakhstan as reported origin, highlighting the role of Thailand as an importer and re-exporter and showing exports were restricted to the years 2004 and 2005 (Lebanon is not party to CITES)

\begin{tabular}{|c|c|c|c|c|c|c|c|c|c|}
\hline Species & Trade & 1987-2003 & 2004 & 2005 & 2006 & 2007 & 2008 & Exporter & Importer \\
\hline $\begin{array}{l}\text { Dendrobates } \\
\text { amazonicus }\end{array}$ & Export & 0 & 20 & 0 & 0 & 0 & 0 & Lebanon & Thailand \\
\hline \multirow[t]{2}{*}{ Dendrobates auratus } & Export & 0 & 100 & 100 & 0 & 0 & 0 & Lebanon & Thailand \\
\hline & Re-export & & & 10 & 20 & 0 & 0 & Thailand & Taiwan \\
\hline \multirow[t]{2}{*}{ Dendrobates azureus } & Export & 0 & 240 & 200 & 0 & 0 & 0 & Lebanon & Thailand \\
\hline & & & & & & 5 & 0 & Thailand & S Korea \\
\hline $\begin{array}{r}\text { Dendrobates } \\
\text { fantasticus }\end{array}$ & Export & 0 & 30 & 30 & 0 & 0 & 0 & Lebanon & Thailand \\
\hline \multirow{2}{*}{$\begin{array}{l}\text { Dendrobates } \\
\text { galactonotus }\end{array}$} & Export & 0 & 100 & 100 & 0 & 0 & 0 & Lebanon & Thailand \\
\hline & Re-export & & & 30 & 7 & 0 & 0 & Thailand & Taiwan \\
\hline Dendrobates imitator & Export & 0 & 0 & 50 & 0 & 0 & 0 & Lebanon & Thailand \\
\hline Dendrobates lamasi & Export & 0 & 40 & 40 & 0 & 0 & 0 & Lebanon & Thailand \\
\hline $\begin{array}{l}\text { Dendrobates } \\
\text { leucomelas }\end{array}$ & Export & 0 & 100 & 100 & 0 & 0 & 0 & Lebanon & Thailand \\
\hline Dendrobates pumilio & Export & 0 & 100 & 100 & 0 & 0 & 0 & Lebanon & Thailand \\
\hline $\begin{array}{l}\text { Dendrobates } \\
\text { reticulatus }\end{array}$ & Export & 0 & 100 & 100 & 0 & 0 & 0 & Lebanon & Thailand \\
\hline \multirow{4}{*}{$\begin{array}{c}\text { Dendrobates } \\
\text { tinctorius }\end{array}$} & Export & 0 & 200 & 200 & 0 & 0 & 0 & Lebanon & Thailand \\
\hline & Re-export & & & 18 & 20 & 0 & 0 & Thailand & Taiwan \\
\hline & Re-export & & & & 6 & 0 & 0 & Thailand & Philippines \\
\hline & & & & & & 30 & 0 & Thailand & S Korea \\
\hline $\begin{array}{l}\text { Dendrobates } \\
\text { ventrimaculatus }\end{array}$ & Export & 0 & 20 & 40 & 0 & 0 & 0 & Lebanon & Thailand \\
\hline Dendrobates spp & Re-export & 0 & 50 & 0 & 0 & 0 & 0 & Lebanon & Thailand \\
\hline \multirow[t]{2}{*}{ Phyllobates bicolor } & Export & 0 & 100 & 100 & 0 & 0 & 0 & Lebanon & Thailand \\
\hline & & & & & & 10 & 0 & Thailand & S Korea \\
\hline Phyllobates terribilis & Export & 0 & 100 & 100 & 0 & 0 & 0 & Lebanon & Thailand \\
\hline \multirow[t]{2}{*}{ Epipedobates tricolor } & Export & 0 & 50 & 50 & 0 & 0 & 0 & Lebanon & Thailand \\
\hline & Re-export & & & & 5 & 0 & 0 & Thailand & South Korea \\
\hline $\begin{array}{l}\text { Cryptophyllobates } \\
\text { azureiventris }\end{array}$ & Export & 0 & 0 & 40 & 0 & 0 & 0 & Lebanon & Thailand \\
\hline
\end{tabular}

numbers of captive-bred versus wild-caught dendrobatid frogs. Gorzula (1996) reported $14 \%$ of the total international trade to be captive-bred, whereas currently $91 \%$ of the individuals are reported as such (with an additional 5\% comprising ranched or F1 captiveborn individuals). Finally, in the late 1980s-early 1990s Japan was the only Asian country to have imported dendrobatid frogs with an average annual import of $\sim 60$ individuals, and no Asian country was listed as a (re-)exporting country.

The present study points to the important role of Asian consumer markets in the trade of dendrobatid frogs (cf. Hou et al. 2006) as well as a relevant role as re-exporters of these species. While there is a substantial international trade in dendrobatid frogs, with many of them being reported as captive-bred, the present study raises some concerns. The species were listed in Appendix II of CITES so as to regulate their international commercial trade. 


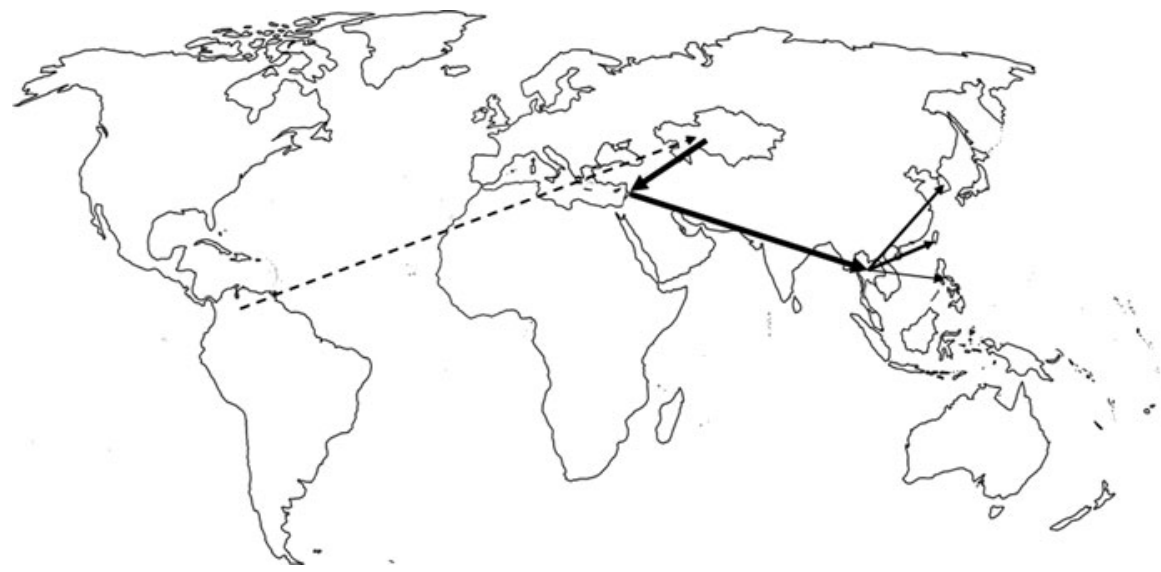

Fig. 1 Trade routes of dendrobatid frogs from Kazakhstan and Lebanon to Thailand and thence to South Korea, Taiwan Province of China and the Philippines. Size of arrows are proportional $\left(\log _{10}\right.$-transformed) to the volumes traded. The dotted line indicates a minimum number of individuals following an assumed route from range States

For 16 of the 32 species traded internationally in 2004-2008, trade between two CITES Parties (Kazakhstan and Thailand) was routed through a non-CITES country (Lebanon) and involved large numbers (Table 1). The question is whether or not these individuals have indeed been bred in captivity or originate from other sources. Kazakhstan reports no trade and Lebanon, as a non-CITES Party, does not report any trade either. In its 8 years as a Party to CITES Kazakhstan has never reported the commercial trade (import or export) of an amphibian to CITES, making the export of captive-bred dendrobatid frogs highly unusual.

While it is difficult to assess properly the impact of this trade for all the species concerned, it is nevertheless illustrative to focus on the trade in a number of endemics from Peru (D. amazonicus, ${ }^{1}$ D. fantasticus, and D. lamasi) and Colombia ( $P$. bicolor and $P$. terribilis). No live individuals of $D$. amazonicus have ever been reported to have been exported from Peru, and their rarity in international trade is corroborated by their absence in the 735 zoos and aquariums that have joined International Species Information System. A few hundred Dendrobates lamasi has been reported in international trade since 1987, but few in recent years, with only 27 individuals present in international zoos and aquariums (no offspring produced in 2008). None have been recorded as exported to Kazakhstan by CITES. Dendrobates fantasticus has not been reported as being exported to Kazakhstan, and while it is traded in slightly higher numbers than D. lamasi, the 60 individuals exported from Kazakhstan are the largest quantities since 1993. Only 13 individuals are reported to be present in public zoos and aquariums, with no offspring reported for 2008 .

Similarly, a few hundred Colombian $P$. bicolor and $P$. terribilis have been traded internationally since the early 1990s, most declared as captive-bred, and none have Colombia as the exporter or as the source country. Both species are kept in moderate numbers in international zoos, 145 and 320 individuals for $P$. bicolor and $P$. terribilis, respectively, with only $P$. bicolor having produced 9 offspring in 2008.

\footnotetext{
${ }^{1}$ It is quite possible that some or even most of the D. amazonicus in trade are in fact the red morph of D. ventrimaculatus, labelled as the former so as to increase their value (Victor J.T. Loehr, in litt.).
} 
Given the infrequent nature of captive-breeding in some species, the significant numbers of captive-bred specimens imported from Kazakhstan via Lebanon into Thailand are remarkable. While for some species the total number of purportedly captive-bred specimens is not very large, and even if they were wild-caught may not have significant impacts on wild populations, it is important to investigate these pathways as they can be used to transport larger number of specimens and of a wider range of species as well. In this light, we urge the CITES Management Authorities from Thailand and Kazakhstan to scrutinize the trade involving captive-bred specimens of Dendrobatidae.

We furthermore recommend the CITES Management Authorities of the range States (Colombia, Peru, Suriname, Brazil amongst others) to follow up on this issue with the Management Authorities in Thailand and Kazakhstan. While the described trade in CITES II-listed poison arrow frogs in Asia may be exceptional, discrepancies in reported levels of international wildlife trade are not (e.g. Blundell and Mascia 2005) and we urge conservationists and others interested in regulating wildlife trade to explore other similar cases, retrospectively or in real time, and report discrepancies to the relevant authorities.

Acknowledgments We thank Steve Gorzula and Matthew Todd for information on the poison arrow trade, and Claire Beastall for preparing the map. We thank Watana Vetayaprasit, Director of the CITES Management Authority of Thailand for providing information on the import of CITES-listed amphibians into Thailand. Victor J.T. Loehr, Maylynn Engler and two anonymous reviewers are thanked for constructive comments.

Open Access This article is distributed under the terms of the Creative Commons Attribution Noncommercial License which permits any noncommercial use, distribution, and reproduction in any medium, provided the original author(s) and source are credited.

\section{References}

Bartlett RD (2003) Poison dart frogs: facts and advice on care and breeding. Barron's Educational Series, Hauppauge

Blundell AG, Mascia MB (2005) Discrepancies in reported levels of international wildlife trade. Conserv Biol 19:2020-2025

Brown JL, Schulte R, Summers K (2006) A new species of Dendrobates (Anura: Dendrobatidae) from the Amazonian lowlands of Peru. Zootaxa 1152:45-58

CITES (2009) CITES glossary. http://www.cites.org/eng/resources/terms/glossary.shtml\#c. Accessed 15 Nov 2009

Clough M, Summers K (2000) Phylogenetic systematics and biogeography of the poison frogs: evidence from mitochondrial DNA sequences. Biol J Linn Soc 70:515-540

Daszak P, Cunningham AA, Hyatt AD (2003) Infectious disease and amphibian population declines. Divers Distrib 9:141-150

Duarte-Quiroga A, Estrada A (2003) Primates as pets in Mexico city: an assessment of the species involved, source of origin, and general aspects of treatment. Am J Primatol 61:53-60

Frost DR (2004) Amphibian species of the world: a taxonomic and geographic reference. http://research.amnh.org/herpetology/amphibia/index.php. Accessed 15 Nov 2009

Gorzula S (1996) The trade in dendrobatid frogs from 1987 to 1993. Herpetol Rev 27:116-123

Hou PCL, Shiau TW, Tu MC, Chen CC, Chen TY, Tsai YF, Lin CF, Wu SH (2006) Exotic animals in the pet shops of Taiwan. Taiwania 51:87-92

Mrosovsky N (1988) The CITES conservation circus. Nature 331:563

Nijman V (2005) In full swing. An assessment of trade in orang-utans and gibbons on Java and Bali, Indonesia. TRAFFIC Southeast Asia, Petaling Jaya

Nijman V (2006) In situ and ex situ status of the Javan gibbon and the role of zoos in conservation of the species. Contrib Zool 75(3-4):161-168

Nijman V (2010) An overview of the international wildlife trade from Southeast Asia. Biodivers Conserv (special issue: conserving Southeast Asia's imperiled biodiversity). doi:10.1007/s10531-009-9758-4 
Nijman V, Shepherd CR (2007) Trade in non-native, CITES-listed, wildlife in Asia, as exemplified by the trade in freshwater turtles and tortoises (Chelonidae) in Thailand. Contrib Zool 76:207-211

Pickett J (1987) Poison arrow frogs, CITES, and other interesting matters. British Herpetol Soc Bull 21: $58-59$

Preece DJ (1998) The captive management and breeding of poison-dart frogs, family Dendrobatidae, at Jersey Wildlife Preservation Trust. Dodo 34:103-114

Schlaepfer MA, Hoover C, Dodd CK (2005) Challenges in evaluating the impact of the trade in amphibians and reptiles on wild populations. Bioscience 55:256-264

Shepherd CR, Sukumaran J, Wich SA (2004) Open season: an analysis of the pet trade in Medan, Sumatra 1997-2001. TRAFFIC Southeast Asia, Petaling Jaya

Symula R, Schulte R, Summers K (2003) Molecular systematics and phylogeography of Amazonian poison frogs of the genus Dendrobates. Mol Phylogenet Evol 26:452-475

Vences M, Kosuch J, Lötters S, Widmer A, Köhler J, Jungfer K-H, Veith M (2000) Phylogeny and classification of poison frogs (Amphibia: Dendrobatidae), based on mitochondrial 16S and 12S ribosomal RNA gene sequences. Mol Phylogenet Evol 15:34-40 